\title{
Prospects of Islamic Microfinance: A Study in India
}

\author{
Huma Mahmood ${ }^{1 *}$, Rusni Hassan ${ }^{2}$, Syed Ahmed Salman ${ }^{3}$ \\ 1, 2 IIUM Institute of Islamic Banking and Finance (IIiBF), International Islamic University Malaysia, Gombak, Malaysia \\ ${ }^{3}$ Faculty of Business and Accountancy, Lincoln University College, Petaling Jaya, Malaysia
}

\section{Keywords \\ Prospects \\ Islamic microfinance \\ India}

Received: 12 May 2020

Accepted: 21 July 2020

Published: 20 October 2020

\begin{abstract}
India being a developing economy is one of the emerging markets in the world. But an obstacle that still stands in its way of development is the scarcity of financial/monetary resources required for sustainable investments. The giants of Microfinance in India are known to be charging high rates and the smaller players follow in their footsteps. For such regions, Interest-free microfinance is what is needed to uplift the minority and take them out of the fangs of poverty. Interest-free microfinance and its implementation can prove to be very useful in eradicating poverty and providing sustainable development of micro-enterprises and the expansion of financial inclusion. Thus, the aim of this study is to examine the prospects of Islamic microfinance in India. The quantitative method is employed, and primary data is collected through a questionnaire. The probability sampling method is used. Out of 500 questionnaires disbursed, 303 are received. The result of the questionnaire shows that majority of the public believes Islamic Microfinance Institions (IMFIs) will aid the poor financially, poverty will be alleviated, it will be beneficial to the society, and will help micro SMEs become more developed. Similarly, majority of the respondents also agreed to IMFIs being ethical, meant for all religions, catering to the needs of the society and help to extend loans without collaterals. This reflects that Islamic Microfinance holds great potential and prospects and will be widely accepted by the public and also the Indian market. Policymakers should consider IMFIs, establish guidelines and promulgate them as this can pave way to a financially more stable India. The limitation of the study is that the outreach was among people with access to the internet. Therefore, perception of those in rural areas, people with no internet and education could not be included. Hence, future research will fulfill this lacuna.
\end{abstract}

(c) 2020 The Author(s). Published by TAF Publishing.

\section{INTRODUCTION}

The financial system in India is broadly categorized into the formal financial system (organised) and the informal financial system (unorganised) (Pathak, 2011). The formal financial system (organised) comprises of the Banking Institutions and the Non-Banking institutions. The Non-Banking institutions are further subdivided into Non-banking Finance Companies (NBFCs) and the Development Finance Institutions (DFIs). The informal financial system (unorganized) comprises of local Bankers, Traders, Landlords, money lenders and pawn brokers. The organised system falls under the charge of the Ministry of Finance, the Reserve Bank of India (RBI), the Securities and Exchange Board of India (SEBI) and other regulatory bodies whilst the unorganised system is scarcely regulated by the Government of India (Pathak, 2011; Ripain, Amirul, \& Mail, 2017).
In July 1982, the government set up the National Bank for Agriculture and Rural Development (NABARD), a Development Finance Institution. NABARD was established to cater to the needs of the agricultural and rural sectors. By promoting and supporting policies, practices and innovations conducive to rural development, the DFI aimed to strengthen rural credit delivery system through institutional development and oversee rural financial institutions such as cooperative banks and regional rural banks. However, post three and a half decades since the nationalization of banks, a large section of the Indian population still remained uncovered by the formal financial system (Pathak, 2011).

This is when an alternative delivery mechanism, known as microfinance, came into existence. These Microfinance institutions (MFIs)came forth to meet the requirements of

\footnotetext{
*corresponding author: Huma Mahmood

†email: humamahmood@gmail.com
} 
the poor and close the gap between demand and supply for micro-finance. According to Task Force (NABARD) microfinance is defined as "those which provide thrift, credit and other financial services and products of very small amounts, mainly to the poor, in rural, semi-urban or urban areas for enabling them to raise their income level and improve living standards" (Srinivas, 2017).

India became one of the developing countries where microfinance industry boomed instantly (V. K. Tripathi, 2014). The prevailing wisdom in the development of the community was that by providing micro-credit to the poorest of the poor, the gap in the formal rural credit sector could be narrowed (Pathak, 2011). Due to the liberalization in India in 1991, many private players were allowed to enter the market to provide microfinance products and services. Microfinance increasingly evolved into an industry that saw the influx of diverse market players attracted by low competition, huge clientele and excellent long-term growth prospects with no regulation. These unregulated and no profit-based MFIs were private entities funded by donor support. To increase the outreach the Non-government OrganizationMFIs started to transform into NBFCs becoming corporate entities and initiated a profit-based model of MFI to ease access to capital for their sustainability (Chakrabarti \& Sanyal, 2016).

Microfinance rose to have a clientele of 31.4 million all over India with $40 \%$ of it concentrated in Andhra Pradesh by 2011 (Chakrabarti \& Sanyal, 2016). Much of the success was due to the shift towards establishing profit-based NBFC-MFIs. But this success was met with a big blow in 2010 when the microfinance sector faced the most devastating repayment crises in its history (Mahmood, Hassan, \& Salman, 2019).

The shift from no profit-based MFIs to profit-based NBFCMFIs enticed the MFIs to be motivated by profit, thereby increasing interest rates to deal with high transaction costs. The use of coercion in the collection of loans, both physical and psychological became a common practice (Chakrabarti \& Sanyal, 2016).

SKS Microfinance, one of the giants of microfinance in India, until today is known to be charging approximately 24 percent rate of interest in Karnataka, Orissa, and Andhra Pradesh. In the southern part of India, Equitas Microfinancing is charging 21-28 percent interest rate approximately and Basic Microfinance asks for 18-24 percent interest rate on small loans. The Grameen Bank in Bangladesh and SEWA in Gujarat also thrive on high interest rates. This defies the sole purpose of Microfinance to increase financial inclusion by serving the poor who are unable to pay the high interest and do not always have collateral for their loans (Hollis \& Sweetman, 2004; Marobhe \& Hembe, 2019). It is astonishing that the poorest of the poor with an income of less than two dollars per day are asked to pay 24 percent interest rate for borrowing money to buy a goat or a bullock cart for their business which maybe their only means of survival where as people in the cities or urban areas are charged minimum interest rates, sometimes even provided with interest free loans for buying a car (Aziz \& Pandet, 2017; Reza, Rusidah, \& Forasidah, 2017).

The regulatory interventions in 2011 and 2012 aimed at reviving the microfinance sector and slowly but steadily the outreach grew to 30.3 million borrowers in 2014. But until today according to the report by Hollis and Sweetman (2004), 41 million people most of who are from the socially weak groups such as the Scheduled Castes, the Scheduled Tribes and Minorities are still struggling for basic facilities like food, shelter, clothing and education.

Interest free microfinance and its implementation can prove to be very useful in eradicating poverty and providing sustainable development of micro-enterprises and the expansion of financial inclusion. It will not only satisfy those below poverty line but also Muslims who are excluded from financial inclusion for the reason that interest is not allowed in their belief. It is from this belief that Islamic microfinance comes to existence (Aziz \& Pandet, 2017).

Islamic Microfinance Institutions (IMFIs) in India have been in existence for a long time and date as far back as 1918. For example, Anjuman Islahul Muslemeen (AIM) was established in 1918 in Bhopal Madhya Pradesh, Patni Cooperative Credit Society was established in 1931, Muslim Fund at Tanda Bawli in 1941, and Islamic welfare societies during the 1970s (Bagsiraj et al., 2002). Many of which are registered as trusts, societies and cooperatives operating in various states e.g. Jammu and Kashmir, Gujarat, Delhi, Bihar, Andhra Pradesh, Karnataka, Kerala, Maharashtra, Tamil Nadu and Utter Pradesh. Therefore, the objective of this research is to examine the prospects of Islamic microfinance in India.

This paper is structured into five parts. First part converted the introduction Part two explores a brief picture of microfinance. The third part of this paper describes the research methodology. Part four illustrates the prospects of Islamic microfinance in India and Part five concludes the paper.

\section{BRIEF OVERVIEW OF MICROFINANCE History of Microfinance}

Microfinance, a term used for a relatively recent financing sector has immensely evolved in the last two decades. It has 
become an important subfield of development and a heartthrob for researchers. The pioneers of microfinance date back to 1983 with the establishment of Grameen Bank by Professor Muhammad Yunus in Bangladesh, BancoSol, Bolivia in 1992 and K-Rep, Kenya in 1987 (Copestake et al., 2016).

Even though microfinance is relatively new, but when defined as financial services for the poor then microfinance is deeply rooted in the history of finance globally. Across the globe informal savings and credit groups have been operating for centuries.

In the 15th century, the first official pawn shop was created by an Italian monk to counter usury practices. The following century Pope Leon X gave pawn shops the official permission to overcome operating costs by charging interest (Pavithra, 2014). In 1700, Jonathan Swift and Irishman created Irish Loan Fund giving out small short-term loans to the poorest people in Ireland thereby providing microcredit to those excluded by commercial banks. It was recorded that the funds gave out credit to 20 percent of all Irish households annually (Hollis \& Sweetman, 2004). This idea eventually expanded all across Europe. In 1864, the first rural credit union was founded by Friedrich Wilhelm Raiffeisen in Germany. This was to provide a platform where poor farmers could be relieved from exploiting money lenders and the inaccessibility of loans from commercial banks. This concept of the financial cooperative proliferated worldwide from Ireland to Indonesia and all across Latin America and the whole of Europe (V. Tripathi \& Tripathi, 2014).

In the 1950 s, loans mainly directed to the agricultural workers were funded by donors and government subsidies. Although, this did not last long as the rate of interest charged was too low and ultimately lead to the depletion of capital. Due time there was not enough funds left to inject into the agricultural economy in the form of microcredit. However, in places where credit unions were owned by its members proved to be more efficient compared to the ones owned by the government or private banks. The second half of the 20th century saw the rise of some successful initiatives in the microfinance industry. Some of the examples are Grameen Bank of Bangladesh, ACCION International in Latin America and the Self-Employed Women's Association Bank in India. By this time the term micro-credit started to be known as microfinance. This happened because the microfinance institutions set up in these times were not just offering loans but other financial services like saving accounts, money transfers and insurance (V. Tripathi \& Tripathi, 2014).

\section{Definition of Microfinance}

As the term microfinance has evolved in the past two decades, so has its definition. The concept of microfinance addressed by many scholars has been defined in different ways. The basis of difference has been according to the objective of the scheme, the type of products offered reflecting the purpose of the establishment and modus operandi of the institutions and also from the perspective of microfinance users.

The Asian Development Bank (2000) stated that "microfinance is the provision of a broad range of financial services such as deposits, loans, payment services, money transfers, and insurance to the poor, low income households and microenterprises." This is similar to the definition of CGAP 2019 that says "Microfinance is often defined as financial services for poor and low-income clients".

In practice, the term is often used to refer to loans and other services provided by Microfinance Institutions (MFIs). However, some scholars who equate microcredit to microfinance deviate from this definition. If the various financial services are made to be interrelated to one another, this could put a negative impact on the industry. If any one of the financial services are unable to achieve their targets, then the loss could envelope other services thereby undermining the benefits to the beneficiaries. This could give rise to financial stress or shock. The poor and the poorest of the society are mainly the ones to absorb the shocks leaving them defenseless against their inability to access microcredit (Cohen \& Young, 2007).

Kapoor and Ojha (2006) in their study state that many poor people are trapped in poverty due to the shocks and debts that prevent them from attaining economic prosperity. They acknowledge that microfinance is an important instrument in helping the poor build their assets but also pointed out on the fact that the inability to protect their assets causes their financial stability through acquiring assets to become a temporary development for the numerous clients of MFIs.

Schreiner (2000), defines microfinance to be formal schemes modeled to improve the well-being of the poor by providing better access to saving services and loans. Therefore, he suggests that for microfinance institutions to discover the poor of the people, the informal financial sector such as money lender, check cashing outlets, pawn shops and loans amongst relatives and friends are all important sources of knowledge to microfinance institutions and are crucial to the poor. Some scholars argue that the financial services should be complemented with other ancillary. Sarkar et al. (2014) in their study stated that mi- 
crofinance apart from financial services also includes skill up-gradation and entrepreneurship development provided to the poor for empowering them to overcome poverty. As mentioned by the Nobel Laureate, Yunus (2007), all humans are born with innate survival skills and the poor already possess some of these innate skills. The drive of the poor to survive is what gave birth to microfinance. If the required financial and non-financial services are provided to the poor, then these skills can empower them to claw out of the clutches of poverty.

The researcher after looking into the various definitions of microfinance and as stated by Karlan and Valdivia (2011) and Sarkar et al. (2014) is of the opinion that the rendering of micro-financial services in its entirety would be the appropriate definition of micro-financing.

\section{Models of Microfinance}

Microfinance institutions provide financial services to the entrepreneurial poor that are tailor made to their needs and conditions. Thus, due to the diverse social, economic, cultural and political backgrounds, diverse models of micro financing have evolved and vary in the way these models are practiced depending on the country and regional locations. The operation of microfinance institutions in today's time has greatly evolved. As stated by Webster (1995) in his study, according to the Grameen Bank there are fourteen different models of micro financing. Some of which and perhaps the popular amongst them are as follows; Joint-Liability Groups (JLG); Village Banks; Self-Help Groups (SHG) and Credit Union.

\section{Microfinance in India}

Microfinance is a channel that provides a wide range of financial services such as deposits, loans, money transfers, payment services and insurance to the poor, low income households and microenterprises (Cohen \& Young, 2007). It caters to unemployed or low-income individuals who have limited sources of raising funds and do not have enough income to become clients of traditional financial institutions to startup a business. Those availing the services provided by microfinance institutions are landless laborers engaged in agriculture, small and marginal farmers, mining and construction, rural artisans and weavers; selfemployed in urban informal sector; self-employed in nonagricultural activities and women.

Microfinance is not a new concept with its history dating back to as far as the 18th century, however, it has in recent times emerged as an effective medium to provide financial services to the poor and the low-income sectors of societies in India and fill the gaps created by the formal banking institutions (Nagaraju \& RameshReddy, 2016). The first microfinance institution to be set up in India was SEWA Bank in 1974 as an Urban Cooperative Bank providing banking services to the self-employed women. Non-Government Organisations (NGOs) in the 1980s, formed informal Self-Help Groups (SHGs) engaged in micro-activities. SHGs were able to successfully meet the needs of their members and also had the potential to grow but the major constraint that stood in their way was getting big loans to finance their activities. (Chakrabarti \& Sanyal, 2016).

To combat this issue, NABARD promulgated the idea of organizing thrift and credit groups among the NGOs as an added activity. It promoted linking Self-Help Groups with banks for funds. Subsequently, in February 1992, with the help of RBI, NABARD launched the Self-help Group-Bank Program which aimed at promoting and financing 500 SHGs across the entire country. NABARD also offered various schemes such as Kisan Credit Card, Watershed Development Scheme, Scheme for Financing Farmers, Women Empowerment, and Rural Entrepreneurship Development Program (REDP) (Pathak, 2011).

The success of NGOs and NABARD encouraged several microfinance institutions to emerge with the aim to help the rural and urban poor and more specifically the women of the Indian society. India soon became one of the largest microfinance markets in the world with the 1990s being the turning point in India's economic history characterized by liberalization of the economy. It was due to this liberalization in 1991 that private players were allowed to provide microfinance products and services and become part of the sector. These private microfinance service providers were called Microfinance Institutions (MFIs). They served as a gateway for financial inclusion since regular banks considered the poor as non-bankable because of the high cost per individual loan and absence of collateral (V. Tripathi \& Tripathi, 2014).

The way microfinance model functioned as seen in Figure 1 below, was that commercial banks or apex institutions like NABARD, SIDBI, and Rashtriya Mahila Kosh (RMK) would lend to MFIs. These MFIs would further lend to groups or individuals (Sanyal, 2007). 


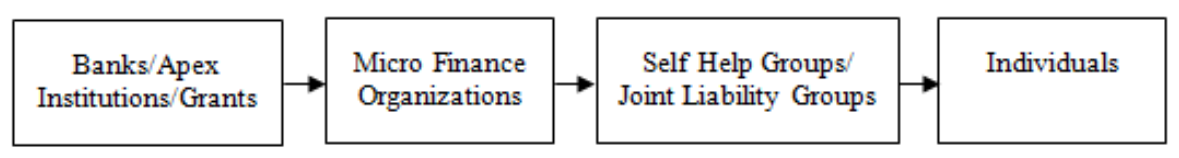

FIGURE 1. Institutional flow of micro finance (Sanyal, 2007)

The MFIs vary significantly in size, outreach and credit delivery methodologies. The lending activities of MFIs were not regulated except for those MFIs registered as NBFCs. The microfinance sector originated from private initiatives that were based on charity and hence were able to operate for a long time without the governments' supervision. The exception to this was NABARD which was $100 \%$ owned by the government of India. Most of the MFIs were NGOs and were funded through donor support in the form of revolving funds and operating grants. By around 1999, they started receiving bulk loans from NABARD, SIDBI and RMK. However, the outreach still remained an issue as MFIs managed to barely reach about $10 \%$ of the 60 million poor families in India (Sinha, 2003).

It was during this time that NGO-MFIs started to transform into NBFCs since access to capital was easier being a corporate entity regulated by the RBI. This in turn also attracted international private equity and professionals who were interested in setting up profit based NBFCs providing financial services to people at the bottom of the wealth pyramid. Some of these NBFCs were Spandana, SHARE Microfin, BASIX India and SKS Microfinance. By 2010, there were 5-10 large and mid-sized NBFC-MFIs which had transformed from NGO-MFI and about the same number of NBFC-MFIs promoted by professionals. There were also 800 NGO-MFIs operating in the sector, but their outreach and loan portfolios were much smaller (Singh, 2013). The private MFIs now covered NGOs, Co-operative Societies and Non-Banking Financial Companies (NBFCs). Therefore, the private MFIs using different delivery models provided a wide range of microfinance products and services. Microfinance progressively evolved into an industry with low competition, little to no regulation, and huge clientele causing diverse market players to enter foreseeing excellent long term growth prospects (Singh, 2013).

The growth of 'for profit NBFC-MFIs' lead to SKS becoming the first MFI in India on 28th July 2010, to float its shares through an initial public offering which was 13 times oversubscribed and drew in leading investment groups like Morgan Stanley, JP Morgan and George Soros Quantum Fund (Singh, 2013). Microfinance was on the rise reaching 31.4 million clients all over India by June 2011. MFIs which were privately owned and SHG-Banks which were stategovernment sponsored, both co-existed and flourished to- gether with their clientele reaching $17.6 \%$ and $4.9 \%$ respectively by year $2010-11$. Almost $40 \%$ of India's microfinance was concentrated in Andhra Pradesh and its capital Hyderabad came to be known as the capital of microfinance in India. The two fastest growing for-profit MFIs 'SKS' and 'Spandana' were based in Andhra Pradesh.

\section{RESEARCH METHODOLOGY}

The research is an exploratory study; hence questionnaire is used for the collection of primary data. The purpose of distributing questionnaire is to examine the perception of public towards the prospects of Islamic Microfinance in India. Secondary data includes various articles, books, journals that will contribute in drafting out a comprehensive picture about the possibilities and prospects of Islamic microfinance in India. Random sampling method is adopted. In order to have the research questions answered, the researcher collects the data from a given population which in this case is the general public of India. Given the vast population of India the researchers do not have the time or resources to analyse the entire population, hence the sampling technique is acquired (Taherdoost, 2018). The questionnaire once completed was designed as a Google form and the link of which was then shared across various online social media applications and via emails. About 500 respondents were sent the link of which 303 responses were received. This sample size is considered to be significant as each variable or question in the data has more than five observations/respondents (Hidayat \& Rafeea, 2014).

In preparing the actual survey questionnaire, five-point Likert-scale is used, from 1 to $5(1=$ strongly disagree to $5=$ strongly agree). The prior researchers who use five-point Likert-scale are Addae (2015), Bagsiraj et al. (2002), Hollis and Sweetman (2004), Hidayat and Rafeea (2014), Hidayat and Rafeea (2014), Htay and Salman (2013), Hassan, Kassim, Majdi, and Salman (2018), Islam and Rahman (2017), Lecossier, Pallot, Crubleau, and Richir (2019), Maiyaki and Ayuba (2015), Mahmood et al. (2019), Subedi (2016), Salman, Rashid, and Htay (2018).

\section{FINDINGS}

\section{Demographic Profile of Respondents}

In this study, out of a total of 303 respondents, 202 (72.6\%) are male respondents and 83 (27.4\%) are female respondents (Refer to Table 1). The percentage shows that the 
male respondents are much higher than the female respondents. In terms of age, in this study, majority of the respondents are from the age group of 31-35 years with 63 respondents (20.8\%), followed by the age group of 21-25 years and 36-40 years with 48 respondents in each representing $15.8 \%$ of the study. The age group of $26-30$ years and 41-45 years had 42 respondents (13.9\%) and 36 respondents $(11.9 \%)$ respectively. The minority of the respondents are from the age groups 51- 60 years, 61- 65 years, 46-50 years and 66 years and above with 24,18 , 16 and 8 respondents representing 7.9\%, 5.9\%, 5.3\% and $2.6 \%$ of the study respectively. The study shows that majority of the respondents are aged 21 to 45 years which represents a total of $78.2 \%$ of the study. This is because the questionnaire was disbursed online with links shared on various social network platforms like Facebook, Instagram, and WhatsApp and via emails, and users of these platforms are found to be predominantly within this age range.

Educational background shows that the majority of the respondents are master's degree holders with 137 respondents representing $45.2 \%$ of the study, followed by the bachelor's degree holders with 114 respondents i.e. 37.6\% of the study. The PhD degree holders are ranked third amongst the majority with 31 respondents contributing to $10.2 \%$ of the questionnaire received. The minority of the respondents have other forms of education that maybe of a lower level with 13 respondents in this category and 8 respondents having diplomas contributing to $4.3 \%$ and $2.6 \%$ respectively.

The target respondents for the questionnaire were Indians from all forms of cultural background, education and religion. Although the questionnaire was distributed online to platforms having members of all religions, the majority of the respondents were Muslims with 287 respondents. Muslims constituted to $94.7 \%$ of the total respondents of the questionnaire received. Responses received from Hindus and Sikhs were in minority with 14 and 2 respondents representing $4.6 \%$ and $0.7 \%$ of the study respectively.

In terms of work profile majority of the respondents chose the 'other' category, academicians, manager, employee and engineer with 76, 66, 41, 39 and 34 respondents representing $25.1 \%, 21.8 \%, 13.5 \%, 12.9 \%$ and $11.2 \%$ respectively. The minority tagged themselves as businessman, bankers and sales executive with 28,16 and 3 respondents respectively. In total, the minority contributes to $15.5 \%$ of the entire study.
TABLE 1. Profile of respondents

\begin{tabular}{|c|c|c|c|}
\hline No & Description & Frequency & Percentage \\
\hline \multirow[t]{4}{*}{1} & Gender & & \\
\hline & Male & 220 & 72.6 \\
\hline & Female & 83 & 27.4 \\
\hline & Total & 303 & 100.00 \\
\hline \multirow[t]{11}{*}{2} & Age range & & \\
\hline & $21-25$ & 48 & 15.8 \\
\hline & $26-30$ & 42 & 13.9 \\
\hline & $31-35$ & 63 & 20.8 \\
\hline & $36-40$ & 48 & 15.8 \\
\hline & $41-45$ & 36 & 11.9 \\
\hline & $46-50$ & 16 & 5.3 \\
\hline & $51-60$ & 24 & 7.9 \\
\hline & $61-65$ & 18 & 5.9 \\
\hline & 66 and above & 8 & 2.6 \\
\hline & Total & 303 & 100.0 \\
\hline \multirow[t]{7}{*}{3} & Education background & & \\
\hline & Diploma & 8 & 2.6 \\
\hline & Bachelor's degree & 114 & 37.6 \\
\hline & Master's degree & 137 & 45.2 \\
\hline & Ph.D. & 31 & 10.2 \\
\hline & Others & 13 & 4.3 \\
\hline & Total & 303 & 100.0 \\
\hline \multirow[t]{8}{*}{4} & Religion & & \\
\hline & Muslim & 287 & 94.7 \\
\hline & Hindu & 14 & 4.6 \\
\hline & Sikh & 2 & .7 \\
\hline & Buddhism & 0 & 0 \\
\hline & Christian & 0 & 0 \\
\hline & Others & 0 & 0 \\
\hline & Total & 303 & 100.0 \\
\hline \multirow[t]{10}{*}{5} & Work Profile & & \\
\hline & Academician & 66 & 21.8 \\
\hline & Employee & 39 & 12.9 \\
\hline & Sales Executive & 3 & 1.0 \\
\hline & Manager & 41 & 13.5 \\
\hline & Banker & 16 & 5.3 \\
\hline & Engineer & 34 & 11.2 \\
\hline & Businessman & 28 & 9.2 \\
\hline & Others & 76 & 25.1 \\
\hline & Total & 303 & 100.0 \\
\hline
\end{tabular}

\section{Prospects of Islamic Microfinance in India}

The questionnaire contained 20 questions on prospects of Islamic microfinance based on a Likert scale with 5 options to each statement. Options range from 1 to 5 where 1 is strongly disagree and 5 strongly agree. (Refer to Table 2) Of the total 303 respondents, $74.9 \%$ agree and strongly agree that IMFIs aid the poor in becoming financially stable. Only $18.5 \%$ neither agree nor disagree and merely $6.6 \%$ disagree and strongly disagree. Similar pattern is observed in all the 
questions that followed. Majority gave a positive response when asked about IMFIs attracting foreign investments into India from GCC countries and boosting agricultural industry with $63.7 \%$ and $68.3 \%$ respectively. Merely $9.6 \%$ and $6 \%$ disagreed to foreign investment inflow and agricultural industry boost respectively. The rest $26.7 \%$ and $25.7 \%$ remained neutral on both matters respectively. It is worth noting that although those who disagree are few in number, the ones who are neutral are greater and significant in number. This could be for reasons like inability to understand the question or no exposure or awareness of the question being asked. This would imply that apart from the majority having a positive outlook, lack of awareness on these matters is quite significant.

The following questions were based on whether having Islamic Microfinance institutions will make micro SMEs become more developed, reduce income gap, alleviate poverty, give benefit to the society, refrain from alcohol and gambling investments, and do justice to financier and borrower both. Majority responded positively with $73.9 \%, 60.4 \%$, $71.3 \%, 75.2 \%, 81.2 \%$ and $77.5 \%$ respectively. Very few respondents disagreed with $4 \%, 12.2 \%, 7.9 \%, 4.3 \%, 4.3 \%$ and $3.3 \%$ respectively. Neutral in the above questions ranged from a minimum of $14.5 \%$ to a maximum of $27.4 \%$.

It is interesting to note that when asked about IMFIs that they refrain from interest-based activities, alcohol and gambling only $4.3 \%$ disagree and $14.5 \%$ are neutral which is second lowest in Table 2. This is in accordance to a study by Mahmood et al. (2019) which shows that majority of the public are aware of Islamic microfinance being free from interest and free from investing in prohibited business activities. This could also be as stated by Nisar (2002) that general public when offered products under the label of 'Islam' trust it blindly and are unable to differentiate between the real Islamic products and the Ponzi schemes. The Ponzi schemes in the past by taking advantage of this faith, tainted the image of honest and true Islamic microfinance institutes and eroded the confidence of many in IMFIs. But the above data shows that although awareness of products and func- tions of IMFIs is very low amongst the respondents, majority believe that IMFIs being Islamic will not be involved in activities that go against Islamic principles. This shows that Muslim population even today, trusts companies with the label of Islam attached to them to be Islamic. This also highlights the high potential and acceptance of Islamic Microfinance amongst the Muslim population of India.

Islam embodies ethics and principles. Hence when respondents were asked about IMFI being ethical, IMFI catering to all religions of the society, IMFI catering to needs of the society, and that IMFI will allow loan without collaterals, majority like the previous questions responded positively with merely a few disagreeing. The respondents in Neutral ranged from $17.8 \%$ to $27.7 \%$ which is greater than respondents who disagreed and strongly disagreed.

The next question was on IMFIs providing products that suit the clients. This question saw the highest number of neutral responses in the Table at 34\%. This could be as stated earlier due to the lack of awareness of products offered by Islamic microfinance institutions. Nonetheless, majority responded positively suggesting that IMFIs being ethical would ultimately provide products that suit their clients. Other questions based on IMFIs reducing unemployment, providing conventional microfinance with an opportunity to expand their product line, IMFIs boosting social harmony and with IMFIs poor will get the basic education they need were all answered in the same pattern with majority agreeing and only a few disagreeing and neutral responses ranging from $18.5 \%$ to $30.7 \%$.

The question that saw the least number of neutral responses at $13.9 \%$ and the second lowest number of those who disagree and strongly disagree at 3.3\% and the highest number of those who agree and strongly agree at $82.8 \%$ was that Muslim population in India being third largest in the world creates a huge potential for Islamic microfinance. From the above analysis, it is clear that Islamic microfinance will be widely accepted with a high demand in India and has great potential and prospects in the Indian Market. 
TABLE 2. Prospects of Islamic microfinance in India

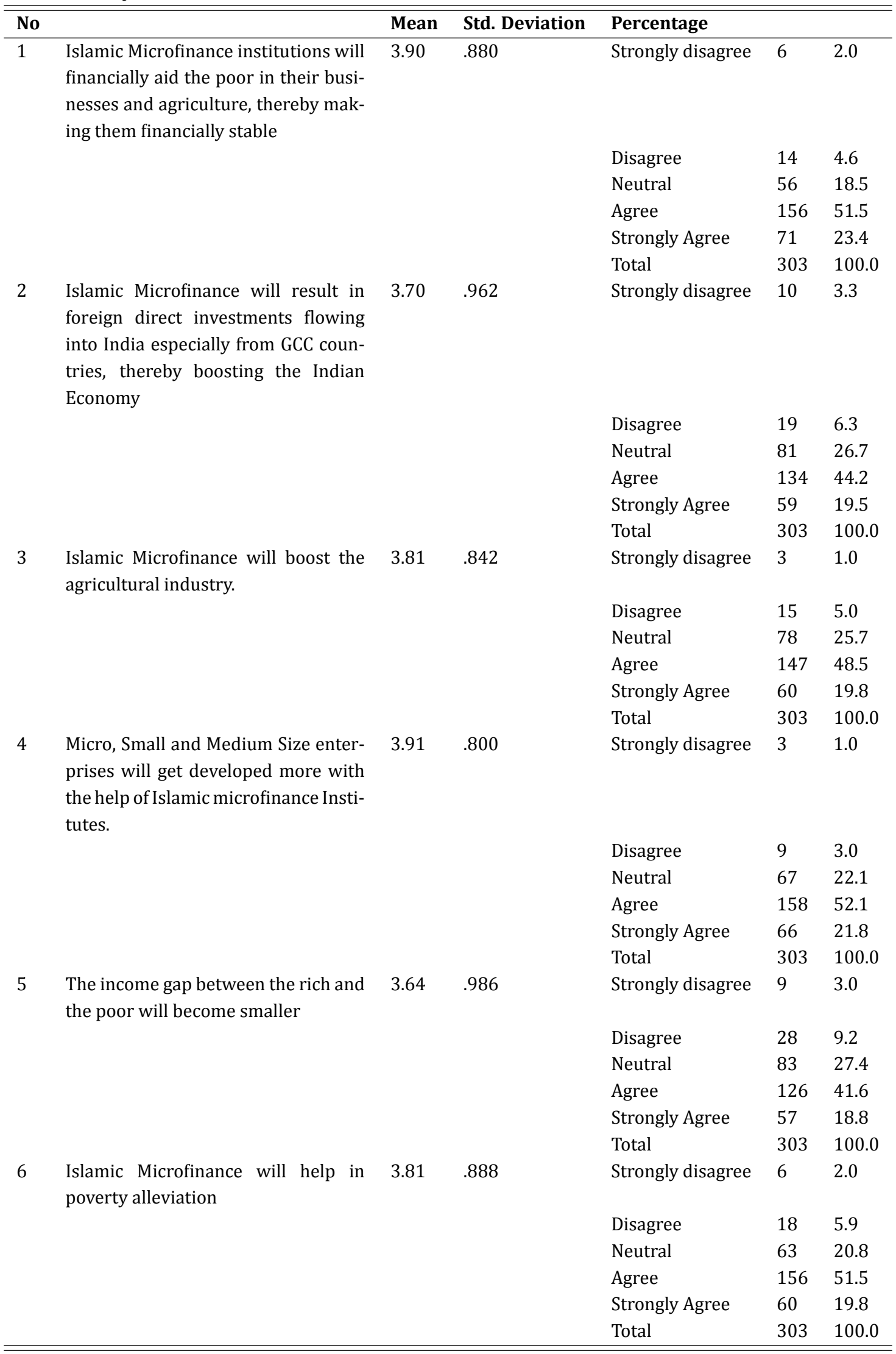


Table 2. Continue..

\begin{tabular}{|c|c|c|c|c|c|c|}
\hline No & & Mean & Std. Deviation & Percentage & & \\
\hline \multirow[t]{6}{*}{7} & $\begin{array}{l}\text { With Islamic Microfinance institu- } \\
\text { tions investments will be made in } \\
\text { businesses that are beneficial for the } \\
\text { society as a whole. }\end{array}$ & 3.93 & .799 & Strongly disagree & 2 & .7 \\
\hline & & & & Disagree & 11 & 3.6 \\
\hline & & & & Neutral & 62 & 20.5 \\
\hline & & & & Agree & 158 & 52.1 \\
\hline & & & & Strongly Agree & 70 & 23.1 \\
\hline & & & & Total & 303 & 100.0 \\
\hline \multirow[t]{6}{*}{8} & $\begin{array}{l}\text { Islamic Microfinance institutions re- } \\
\text { frain from investments in businesses } \\
\text { like alcohol, gambling and interest- } \\
\text { based companies }\end{array}$ & 4.22 & .908 & Strongly disagree & 5 & 1.7 \\
\hline & & & & Disagree & 8 & 2.6 \\
\hline & & & & Neutral & 44 & 14.5 \\
\hline & & & & Agree & 103 & 34.0 \\
\hline & & & & Strongly Agree & 143 & 47.2 \\
\hline & & & & Total & 303 & 100.0 \\
\hline \multirow[t]{6}{*}{9} & Islamic Microfinance does justice to & 4.03 & .831 & Strongly disagree & 4 & 1.3 \\
\hline & & & & Disagree & 6 & 2.0 \\
\hline & & & & Neutral & 58 & 19.1 \\
\hline & & & & Agree & 144 & 47.5 \\
\hline & & & & Strongly Agree & 91 & 30.0 \\
\hline & & & & Total & 303 & 100.0 \\
\hline \multirow[t]{6}{*}{10} & Islamic Microfinance institutions will & 3.71 & .911 & Strongly disagree & 6 & 2.0 \\
\hline & & & & Disagree & 21 & 6.9 \\
\hline & & & & Neutral & 84 & 27.7 \\
\hline & & & & Agree & 137 & 45.2 \\
\hline & & & & Strongly Agree & 55 & 18.2 \\
\hline & & & & Total & 303 & 100.0 \\
\hline \multirow[t]{6}{*}{11} & Islamic Microfinance does not only & 4.09 & .809 & Strongly disagree & 2 & .7 \\
\hline & & & & Disagree & 7 & 2.3 \\
\hline & & & & Neutral & 54 & 17.8 \\
\hline & & & & Agree & 140 & 46.2 \\
\hline & & & & Strongly Agree & 100 & 33.0 \\
\hline & & & & Total & 303 & 100.0 \\
\hline \multirow[t]{6}{*}{12} & Islamic Microfinance is a concept not & 3.97 & .887 & Strongly disagree & 6 & 2.0 \\
\hline & & & & Disagree & 11 & 3.6 \\
\hline & & & & Neutral & 55 & 18.2 \\
\hline & & & & Agree & 146 & 48.2 \\
\hline & & & & Strongly Agree & 85 & 28.1 \\
\hline & & & & Total & 303 & 100.0 \\
\hline
\end{tabular}


Table 2. Continue..

\begin{tabular}{|c|c|c|c|c|c|c|}
\hline \multicolumn{2}{|l|}{ No } & \multirow{2}{*}{$\begin{array}{l}\text { Mean } \\
4.07\end{array}$} & \multirow{2}{*}{$\begin{array}{l}\text { Std. Deviation } \\
.811\end{array}$} & \multicolumn{3}{|l|}{ Percentage } \\
\hline \multirow[t]{6}{*}{13} & Islamic Microfinance will give way to & & & Strongly disagree & 2 & .7 \\
\hline & & & & Disagree & 8 & 2.6 \\
\hline & & & & Neutral & 54 & 17.8 \\
\hline & & & & Agree & 143 & 47.2 \\
\hline & & & & Strongly Agree & 96 & 31.7 \\
\hline & & & & Total & 303 & 100.0 \\
\hline \multirow[t]{6}{*}{14} & Islamic Microfinance not only caters & 4.01 & .785 & Strongly disagree & 2 & .7 \\
\hline & & & & Disagree & 7 & 2.3 \\
\hline & & & & Neutral & 59 & 19.5 \\
\hline & & & & Agree & 154 & 50.8 \\
\hline & & & & Strongly Agree & 81 & 26.7 \\
\hline & & & & Total & 303 & 100.0 \\
\hline \multirow[t]{6}{*}{15} & Islamic Microfinance provides prod- & 3.78 & .794 & Strongly disagree & 1 & .3 \\
\hline & & & & Disagree & 9 & 3.0 \\
\hline & & & & Neutral & 103 & 34.0 \\
\hline & & & & Agree & 133 & 43.9 \\
\hline & & & & Strongly Agree & 57 & 18.8 \\
\hline & & & & Total & 303 & 100.0 \\
\hline \multirow[t]{6}{*}{16} & Islamic microfinance provides a new & 3.78 & .826 & Strongly disagree & 4 & 1.3 \\
\hline & & & & Disagree & 9 & 3.0 \\
\hline & & & & Neutral & 93 & 30.7 \\
\hline & & & & Agree & 141 & 46.5 \\
\hline & & & & Strongly Agree & 56 & 18.5 \\
\hline & & & & Total & 303 & 100.0 \\
\hline \multirow[t]{6}{*}{17} & Islamic microfinance may reduce & 4.02 & .840 & Strongly disagree & 2 & .7 \\
\hline & & & & Disagree & 12 & 4.0 \\
\hline & & & & Neutral & 56 & 18.5 \\
\hline & & & & Agree & 142 & 46.9 \\
\hline & & & & Strongly Agree & 91 & 30.0 \\
\hline & & & & Total & 303 & 100.0 \\
\hline \multirow[t]{6}{*}{18} & Muslim population in India stands at & 4.15 & .816 & Strongly disagree & 3 & 1.0 \\
\hline & & & & Disagree & 7 & 2.3 \\
\hline & & & & Neutral & 42 & 13.9 \\
\hline & & & & Agree & 140 & 46.2 \\
\hline & & & & Strongly Agree & 111 & 36.6 \\
\hline & & & & Total & 303 & 100.0 \\
\hline
\end{tabular}


Table 2. Continue..

\begin{tabular}{|c|c|c|c|c|c|c|}
\hline No & & Mean & Std. Deviation & Percentage & & \\
\hline \multirow[t]{6}{*}{19} & $\begin{array}{l}\text { Islamic Microfinance will boost the } \\
\text { social harmony in the society. }\end{array}$ & 3.98 & .824 & Strongly disagree & 2 & .7 \\
\hline & & & & Disagree & 9 & 3.0 \\
\hline & & & & Neutral & 67 & 22.1 \\
\hline & & & & Agree & 141 & 46.5 \\
\hline & & & & Strongly Agree & 84 & 27.7 \\
\hline & & & & Total & 303 & 100.0 \\
\hline \multirow[t]{6}{*}{20} & With Islamic Microfinance institu- & 3.86 & .878 & Strongly disagree & 3 & 1.0 \\
\hline & & & & Disagree & 16 & 5.3 \\
\hline & & & & Neutral & 75 & 24.8 \\
\hline & & & & Agree & 136 & 44.9 \\
\hline & & & & Strongly Agree & 73 & 24.1 \\
\hline & & & & Total & 303 & 100.0 \\
\hline
\end{tabular}

\section{CONCLUSION}

The survey on prospects of Islamic microfinance consisting of 20 questions based on Likert scale with 5 options yielded promising results. The mean calculated in the results range from 3.64 being the lowest to 4.22 being the highest. 7 out of the 20 questions had mean above 4 , showing higher average compared to the rest. The Standard deviations in all the questions were below 1 with the highest being 0.986 and the lowest being 0.784 . Majority of the results were below 0.9 . Hence, this shows that the data results are significantly consistent. This data result makes it evident that Islamic microfinance has great potential and prospects in India. Furthermore, on examining the prospects of conventional microfinance in India, the results corroborate the demand and wide acceptance of Islamic microfinance among the public and also the Indian market. This study will pave way for more areas of research on Islamic microfinance which is progressively becoming an alternate to conventional microfinance across the globe especially in times of economic crisis and recession.

\section{REFERENCES}

Addae, J. A. (2015). Effect of microfinance on women's empowerment: A review of the literature. ADRRI Journal of Arts and Social Sciences, 13(8), 1-15.

Asian Development Bank. (2000). Finance for the poor: Microfinance development strategy. Retrieved from https:// bit.ly/2FSHvfo

Aziz, A., \& Pandet, B. (2017). Islamic microfinance in Indian perspective. Micro Finance Journal, 1(1), 52-58.

Bagsiraj, M., et al. (2002). Islamic financial institutions of India: Their nature, problems and prospects. Chapters, 5(8), 45-70.

Chakrabarti, R., \& Sanyal, K. (2016). Microfinance and Financial inclusion in India. In, Financial inclusion in Asia. London, UK: Springer.

Cohen, M., \& Young, P. (2007). Using microinsurance and financial education to protect and accumulate assets. New York, NY: Brookings Press.

Copestake, J., Johnson, S., Cabello, M., Goodwin-Groen, R., Gravesteijn, R., Humberstone, J., ... Titus, M. (2016). Towards a plural history of microfinance. Canadian Journal of Development Studies, 37(3), 279-297.

Hassan, R., Kassim, S., Majdi, H., \& Salman, S. A. (2018). Examining the innovative minds of takaful consumers: The case of Malaysia. Indian Journal of Public Health Research \& Development, 9(12), 2652-2655.

Hidayat, S. E., \& Rafeea, A. M. (2014). Public awareness towards takaful concept and principles: A survey in Bahrain. International Journal of Excellence in Islamic Banking and Finance, 182(1784), 1-31. doi:https://doi.org/10.12816/0010778

Hollis, A., \& Sweetman, A. (2004). Microfinance and famine: The Irish loan funds during the great famine. World Development, 32(9), 1509-1523. doi:https://doi.org/10.1016/j.worlddev.2004.04.002 
Htay, S. N. N., \& Salman, S. A. (2013). Viability of islamic insurance (takaful) in India: SWOT analysis approach. European Studies Review, 5(7), 145-160.

Islam, J. U., \& Rahman, Z. (2017). Awareness and willingness towards Islamic banking among Muslims: An Indian perspective. International Journal of Islamic and Middle Eastern Finance and Management, 10(1), 92-101. doi:https://doi.org/ 10.1108/IMEFM-01-2016-0017

Kapoor, S., \& Ojha, R. K. (2006). Vulnerability in rural areas: Potential demand for microinsurance. International Journal of Rural Management, 2(1), 67-83. doi:https://doi.org/10.1177/097300520500200104

Karlan, D., \& Valdivia, M. (2011). Teaching entrepreneurship: Impact of business training on microfinance clients and institutions. Review of Economics and Statistics, 93(2), 510-527.

Lecossier, A., Pallot, M., Crubleau, P., \& Richir, S. (2019). Construction of an instrument to evaluate the user experience of a group of co-creators in the upstream innovation process. International Journal of Services Operations and Informatics, 10(1), 17-42. doi:https://doi.org/10.1504/IJSOI.2017.086585

Mahmood, H., Hassan, R., \& Salman, S. A. (2019). A survey on awareness and knowledge of Islamic Microfinance in India. International Journal of Physical and Social Science, 9(10), 1-11.

Maiyaki, A., \& Ayuba, H. (2015). Consumers' attitude toward Islamic insurance services (takaful) patronage in Kano Metropolis, Nigeria. International Journal of Marketing Studies, 7(2), 27-50. doi:https://doi.org/10.5539/ijms.v7n2p27

Marobhe, M., \& Hembe, L. (2019). The nexus between dividend policy and financial gearing of listed non financial companies in Tanzania. International Journal of Business and Administrative Studies, 5(5), 294-302. doi:https://dx.doi.org/10 .20469/ijbas.5.10004-5

Nagaraju, R., \& RameshReddy, V. (2016). Operation, issues and challenges of micro-finance in India. Indian Journal of Economics and Development, 4(9), 1-4.

Nisar, S. (2002). The state of islamic finance in India: Strengths and weaknesses. Review of Islamic Economics, 6(8), 87-100.

Pathak, B. V. (2011). The indian financial system: Market, institution and services. New Delhi, India: Pearson.

Pavithra, J. (2014). A study on performance of NPAS and loan outsandings of SHG linkage programme In Inidia. Havard Review, 2(1), 178-188.

Reza, F., Rusidah, S., \& Forasidah. (2017). The influence of interpersonal communication and organizational culture on job satisfaction of academics university Achmad Yani Banjarmasin. International Journal of Business and Economic Affairs, 2(6), 310-316. doi:https://doi.org/10.24088/ijbea-2017-25005

Ripain, N., Amirul, S. M., \& Mail, R. (2017). Financial literacy and SMEs' potential entrepreneurs: The case of Malaysia. Journal of Administrative and Business Studies, 3(2), 60-68. doi:https://doi.org/10.20474/jabs-3.2.1

Salman, S. A., Rashid, H. M. A., \& Htay, S. N. N. (2018). The impact of internal forces on acceptance of takaful by insurance policy-holders in India. Journal of Islamic Accounting and Business Research, 5(8), 56-70.

Sanyal, K. (2007). Legislative brief on the micro finance sector (development and regulation) bill. PRS Legislative Research, 21(7), 543-567.

Sarkar, T., Konar, A., Chakraborty, I., Sukul, N. C., Sukul, A., \& Chakravarty, R. (2014). Transmission of the effect of mercurius corrosivus 30 ch on $\alpha$-amylase in cell free medium through water. International Journal of High Dilution Resarch, 13(47), 67-80. doi:https://doi.org/10.1177/097215090600700206

Schreiner, M. (2000). Informal finance and the design of microfinance. New York, NY: Washington University Press.

Singh, D. (2013). A study of success of first IPO of SKS microfinance. Global Journal of Management and Business Studies, $3(2), 163-170$.

Sinha, S. (2003). Financial services for low income families: An appraisal. IIMB Management Review, 15(2), 54-65.

Srinivas, H. (2017). Summary and recommendations of the task force on supportive policy and regulatory framework for microfinance. Retrieved from https://bit.ly/3iQhY5o

Subedi, B. P. (2016). Using likert type data in social science research: Confusion, issues and challenges. International Journal of Contemporary Applied Sciences, 3(2), 36-49.

Taherdoost, H. (2018). Sampling methods in research methodology; how to choose a sampling sampling methods in research methodology; how to choose a sampling technique for. International Journal of Academic Research in Management, 5(2), 18-27. doi:https://doi.org/10.2139/ssrn.3205035 
Tripathi, V., \& Tripathi, V. (2014). Recent development of microfinance in India. Management Review, 5(8), 1-36. doi: https://doi.org/10.2139/ssrn.2462251

Tripathi, V. K. (2014). Microfinance-evolution, and microfinance-growth, of India. International Journal of Development Research, 4(5), 1133-1153.

Webster, D. (1995). The urban environment in Southeast Asia: Challenges and opportunities. Southeast Asian Affairs, 1(14), 89-107. doi:https://doi.org/10.1355/SEAA95F

Yunus, M. (2007). Banker to the poor: Micro-lending and the battle against world poverty. New York, NY: PublicAffairs. 